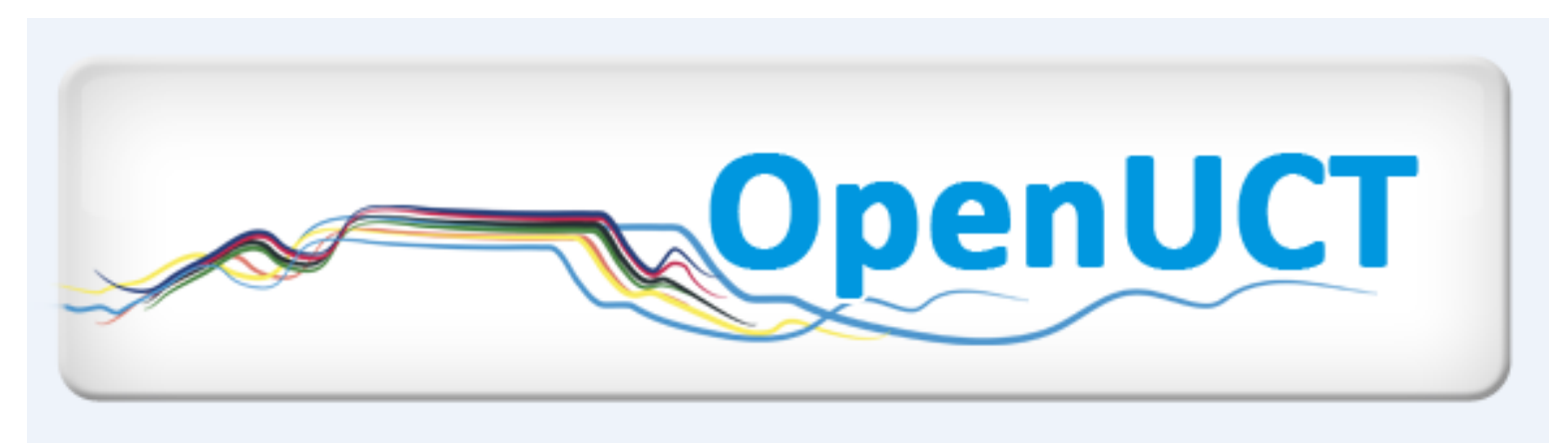

This is the author-approved manuscript version of a journal article published in:

Masango, C. 2009. Understanding copyright in support of scholarship: some possible challenges to scholars and academic librarians in the digital environment? International Journal of

Information Management. 29: 232-236. DOI: 10.1016/j.ijinfomgt.2008.10.003.

It is made available under the terms of agreement between the author and the journal, and in accordance with the University of Cape Town's Open Access Policy for the purposes of research, teaching and private study.

http://www.openuct.uct.ac.za/sites/default/files/UCTOpenAccessPolicy.pdf 


\title{
Understanding copyright in support of scholarship: Some possible challenges to scholars and academic librarians in the digital environment?
}

\author{
Charles A. Masango \\ Department of Research and Innovation, University of Cape Town, South Africa \\ E-mail address: Charles.masango@uct.ac.za
}

Charles A. Masango is a Research Development Co-ordinator with the Emerging Research Programme, Department of Research and Innovation at the University of Cape Town. He has a PhD specialising in contemporary copyright fair dealing management issues. He has an LLB. from the University of Yaoundé, Cameroon; a Postgraduate Diploma in Library and Information Science from the University of Botswana; and a Masters in Library and Information Science from the University of Cape Town where he did his Ph.D. as well. Before joining the Emerging Researcher Programme, he was a lecturer in the Department of Information and Library Studies, University of Cape Town. He also taught at the Department of Library and Information Science, University of Fort Hare prior to his appointment in UCT.

\begin{abstract}
A b s tract
This paper examines the rationale for copyright and how the copyright exemption of the law promotes scholarship. It examines the possible challenges that may be faced by scholars and academic librarians in implementing the copyright fair dealing exemption in the digital environment following that digital information is protected by copyright law and licensing agreements. The paper attempts to propose possible measures that could be implemented for copyright exceptions to better function and promote scholarship in the digital environment.
\end{abstract}

Keywords: copyright, fair dealing exemption, academic librarians, licensing agreements

\section{Introduction}

Copyright is a procedure whereby the originator of a recorded work acquires a series of rights over the work created, including copying, publishing, performing, broadcasting and adaptation (Prytherch, 2000), for a determined period of time. The aim of this paper is to examine the rationale for copyright and how the copyright exemption of the law promotes scholarship. The raison d'être for this examination stem from the fact that digital information is protected by copyright law and licensing agreements. In order to examine copyright and how the copyright exemption promotes scholarship, this paper first examines the origin and aim of copyright law and the fair dealing exemption. How the content of the fair dealing exemption changed with the emergence of new reprographic technology is discussed. Secondly, the paper examines how certain legislation view the application of the fair use or fair dealing exemption in the digital environment. The protective mechanisms of copyrighted works are examined. Thirdly, the paper examines the possible challenges that may be faced by scholars and academic librarians in implementing the copyright fair dealing exemption in the digital environment following that digital content is protected by copyright law and licensing agreements. Finally, the paper attempts to propose possible measures that could be implemented for copyright exemptions to better function and promote scholarship in the digital environment.
2. Origin and rationale of copyright law and fair dealing exemption

The first Copyright Law - the Statute of Anne - was promulgated in 1710 in England. The objective of the act was to encourage 'learned men to compose and write useful work' (Leaffer, 1989). In order to accomplish the aim of the 1710 law, scholars and researchers had to copy or quote from others works that could be found in periodical presses or book reviews without infringing the copyright of the first work. Among the methods permitted by law to quote or copy others works without infringing the copyright of the first work is by applying the fair dealing exemption clause. Other methods through which copying of other peoples works without infringing copyright are permitted is by either seeking permission from the copyright holder of the work or copying works that are in the public domain.

The concept of the fair dealing exemption emerged from early 18th century British case law (McDonald, 1999) and evolved from the specific technological and social circumstances of the time. The 'fair dealing' concept first started in 1803. This was when Lord

Ellenborough in the case of Cary v. Kearsley ${ }^{1}$ asked whether the work that was the centre of the dispute was 'used fairly' (Patry, 1995). In this case the plaintiff who was the author of 'The Book of Roads', sued the defendant for infringement for having used the same names of certain places and distances in his work. The defendant's fault was aggravated as the mistakes that the plaintiff had in his work were also found in the defendant's work. Lord Ellenborough remarked, 
That part of the work of one author is found in another, is not of itself piracy, or sufficient to support an action; a man may fairly adopt part of the work of another; he may so make use of another's labours for the promotion of science, and the benefit of the public; but having done so, the question will be, Was the matter so taken used fairly with that view, and without what I may term the animus furandi (good faith). . .(Patry, 1995).

In 1839, there was an express use of the term 'fair use' in its current combination. In Lewis v. Fullarton, ${ }^{2}$ the plaintiff published a work partly composed of compilations and selections from other works and partly of original authorship. The plaintiff claimed that the defendant infringed his work by copying a considerable portion. The court refused the defendant's defence that he had merely made a fair use of a former publication on the same subject. The court found that 'the defendant had not made any productive, creative use of the plaintiff's work; instead he had merely copied it' (Patry, 1995). In fair use the 'communication of the same knowledge of the original' is prohibited (Patry, 1995)

It is worth noting that notwithstanding that the exemption was coined as 'fair use', and countries like the United States. refer to it as such, there are countries like South Africa that refer to the exemption as 'fair dealing'. The rationale for countries referring to the exemption as 'fair dealing' may be because although fair use is more broader than fair dealing, the latter is more detailed than the former (Rimmer, 2004).

The copyright fair dealing exemption allows individuals to copy portions of works for certain purposes such as research, criticism, teaching, and under certain circumstances that will not interfere with the legitimate rights of the copyright holders (Amen, Keogh, $\&$ Wolff, 2002). The function of the exemption is to balance the rights of publishers and users of copyrighted works. The exemption expressly impacts on all copying of printed copyrighted works as it is intended to avoid the rigid application of the copyright law when such an application would defeat the law's underlying purpose (Loundy, 1995). The exemption frees users of information from the obligation to ask permission or pay a fee for a copy and use of copyrighted works (Harper, 2001).

Notwithstanding the function of the fair dealing exemption, its content changed with the emergence of new reprographic technologies. The most significant change was in 1974. In late 1974 Xerox that monopolized the copier business made an estimated 1700 patents to its competitors. Benefiting from the 1700 patents the Japanese companies entered the copier market. They manufactured smaller photocopiers and sold the machines for the cost that Xerox produced the same machines (Jacobson \& Hillkirk, 1986). Because it became cheaper to purchase photocopies it became easier for anyone to copy any printed work with relatively little finance. In order to prevent the possible marketing of the photocopied works, the content of the fair dealing exemption changed and was codified in countries copyright acts. The content of the fair dealing exemption stipulated that fair dealing exemption was permitted for educational purposes, but not for commercial grounds. The marketing of the copied works negated the exemption.

\section{How certain legislation view its application in the digital environment: invalid application?}

It can be argued that for countries to foster the objective of the first copyright law of 1710 , countries in their copyright acts expressly provides a clause of either 'fair dealing' or 'fair use' exemption in their copyright acts. In the United States, for example, the 1976 Act codified the existing judicial defence of 'fair use' in section 107 by expressly stipulating that:

In determining whether the use made of a work in any particular case is a fair use the factors to be considered shall include:

(1) the purpose and character of the use, including whether such use is of a commercial nature or is for non-profit educational purposes;

(2) the nature of the copyrighted work;

(3) the amount and substantiality of the portion used in relation to the copyrighted work as a whole; and

(4) the effect of the use upon the potential market for or value of the copyrighted work (United States Copyright Act of, 1976).

This United States Act of 1976 spells out the various conditions under which fair use will be applied in a case of copying or reproducing copyrighted works.

In South Africa, the 1978 Copyright Act stipulates in sections $12(1)$

Copyright shall not be infringed if a literary or musical work is used solely, and then only to the extent reasonably necessary:

(a) for the purposes of research or private study by, or the personal or private use of, the person using the work;

(b) for the purposes of criticism or review of that work or of another work; or

(c) for the purpose of reporting current events-in a newspaper, magazine or similar periodical; or by means of broadcasting or in a cinematograph film:

Provided that, subject to the provisions of Section 13, the expression 'used' shall not be constructed as authorizing the making of a copy of the whole or a substantial part of the work in question. Provided further, in the case of paragraphs (b) and (c) (i), that the source shall be mentioned, as well as the name of the author if it appears on the work (South Africa Statutes, 2000, p. 220; Copeling, 1978, p. 41).

Section 13 of the act provides, 'The reproduction of a work shall be permitted as prescribed, but in such a manner that the reproduction is not in conflict with a normal exploitation of the work and is not unreasonably prejudicial to the legal interests of the author (South Africa Statutes, 2000, p. 220; Copeling, 1978, p. 48).

However, although the fair use exemption allows copying of printed copyrighted works and its content was changed as new reprographic technologies emerged, nations such as the United States in its Digital Millennium Copyright Act (DMCA) 1998, and Australia in the Copyright Amendment (Digital Agenda) Act 2000 (Lahore \& Rothnie, 2004), expressly states that the print media fair dealing exemption is applicable in the digital environment. It can be said that this is inapt. The technology of digitization is a new reprographic technology. When the fair use exemption was being designed both the reproduced and original text from where the reproduction was done were in a physical format. This was necessary as there were no possibilities for the reproductive technologies to reproduce or copy texts that were not in hard copies. This is howeve contrary in the digital environment as digital works can be converted into hard copy text and vice versa. In this new technology of digitization, scholars have the opportunity to manipulate, alter, reformat, or erase digital information (Neacsu, 2002). In the digital environment, scholars have the possibility to locate digital information from any computer that is connected to the Internet and distribute to other scholars (Peters, 2003). Following the advantages and convenience that the technology of digitization offers to scholars, corporate rights holders no longer sell copies of 
works, as they did during the dominance of print information but sell access through access licences (McCracken, 2004), in exchange for a fee (Matheson, 2002). Access licensing agreements are legal agreements between two or more parties that allow an intellectual resource owned by the licensor to be used by the licensees for a fixed duration of time (Fowler, 2005).

\subsection{Protective mechanisms for copyrighted works}

One can argue that while print material is protected by copyright law, digital information is protected by both copyright law and licensing agreement. This is because for works to be protected by copyright law such works must be presented in literary form. According to Band (2008), in the print environment once ink flows from a pen onto paper, copyright applies. In the digital environment once works are presented in literary form and such works can be read on a computer screen, copyright applies. Hence when materials are in literary form, they are protected by copyright 'whether or not they are published' (The British Academy and The Publishers Association, 2008). Corroborating this view, the Copyright Act of USA for example stipulates that copyright prevails 'in original works of authorship fixed in any tangible medium of expression. ..., from which they can be perceived, reproduced, or otherwise communicated, either directly or with the aid of a machine or device' (Copyright Act, 1976, as amended, [n.d.]). Following this view, it can be argued that since digital information is in literary form, it is protected by copyright law. Because digital information is in literary form, it can be loaded into a computer's Random Access Memory (RAM) be reproduced and distributed. Where for example, the material in the RAM is of a Portable Document Format (PDF), any reproduction that is made of the material is a replica of the original text. This is because PDF text are 'designed to specify printable pages' and their 'content is optimised for letter-sized sheets of paper' (Nielsen, 2001).

Hence, following the advantages that digital information provides to users of information as the users can manipulate the information, the producers of the information believe that copyright law alone cannot protect the information. Protecting the information through licensing agreements as well would increase their chances to recuperate more alleged lost revenues from copying (Sprigman, 2002). Also, access licences is needed as it forbid unauthorized users, it stipulates the contractual obligations to be honoured, and legal terms such as assignment, termination rights, and stipulates how applicable law should be applied (Davis, 1999).

\section{Scholars and academic librarians' possible challenges?}

Licensing agreements do not expressly encompass the fair dealing exemption. Although access licences incorporate a fair dealing exemption or an analogy to one, as the licences do nothing to prevent authorized users from downloading and printing copies of texts for research purposes, since the licences exclude unauthorized users, one can argue that it does not apply the exemption. BiblioLine for example, is a metadata database service provided by the National Information Services Corporation (NISC). NISC subscriber rights under its agreement are limited to authorized users who can print or otherwise use the metadata content for scholarly purposes (BiblioLine Annual License and Subscription Agreement, 2007). The fair dealing exemption does not make any distinction between authorized and unauthorized users. The fair dealing exemption 'encourage the flow of information essential to innovation, progress and democratic discourse' (Trosow, 2003). Hence, one can argue that the implied provision of the fair dealing exemption in licensing agreements does not only help to confuse users of the information but also the librarians whose duties are to supply the information. For example, where a licensing agreement expressly accepts copying, the agreement does not clarify the law that governs such copies when the information is transformed into hard copy. Following the rules that govern the two formats of information, digital information is governed by copyright law and licensing agreements while print information is protected by copyright law. Hence, in cases where digital information is converted to print information, users and librarians cannot differentiate when licensing agreements would apply and where it ceases to apply.

Furthermore, the vagueness of licensing agreements to clarify the limits of their existence, places librarians in difficulties when they have to send information that can only be found in digital format through Inter Library Loans (ILL) as some licences permit ILL. For example, ScienceDirect permits ILL (ScienceDirect Subscriber and Licence, 1999). Most of the librarians may rightfully refuse to send information that can only be found in electronic databases through ILL on the premise that the requester of the information is an unauthorized person to use such information. Most if not all digital content information forbids unauthorized users access to the information. This lack of clarity in licensing agreements inhibits users from accessing digital information sources and services thereby inhibiting scholarship, as those who are not authorized to access the information cannot use it.

The incorrect application of the fair use and fair dealing exemption in the digital environment by the United States in its Digital Millennium Copyright Act (DMCA) (1998), and Australia in the

Copyright Amendment (Digital Agenda) Act 2000 may also inhibit scholarship. This is because the DMCA and the Digital Agenda Acts stipulates that the fair use or fair dealing exemption in the print environment should be applied in the digital environment. Hence, for example, a scholar who is an authorized user of a digital content may be tempted to believe that an unauthorized user of a digital content may copy digital works under fair use or fair dealing exemption if it is for scholarship. This type of perception may inhibit other authorized users access to the digital content and hence scholarship when the rights holders decide to terminate or temporarily suspend the contract. For example, the Elton B. Stephens Company (EBSCO) Host database states:
[. . . If EBSCO becomes aware of a material breach of the rights of the LICENSEE under this AGREEMENT that EBSCO reasonably believes will cause immediate and severe economic injury, EBSCO will notify the LICENSEE immediately in writing and shall have the right to temporarily suspend the LICENSEE's access to the Product(s). LICENSEE shall have the right to remedy the breach within thirty $(30)$ days, upon receipt of written notice from EBSCO. Once the breach has been remedied or the breaching activity halted, EBSCO shall immediately reinstate access to the Product(s). If the LICENSEE does not satisfactorily remedy the breaching activity within thirty $(30)$ days, EBSCO may terminate this AGREEMENT upon written notice to the LICENSEE [. . . ] (EBSCO publishing product license agreement, 2005).

It can be said that if EBSCO Host terminates the contract othe authorized scholars who would have wanted to copy information for scholarship will not be able to do so. If on the other hand EBSCO Host suspends the contract, the scholars will not be able to copy any information during the period that the contract is suspended.

Furthermore, where librarians for example, incorrectly allow unauthorized scholars to copy digital content within the fair use or fair dealing exemption because it is for scholarship may warrant rights holders to withhold further supplies of the content of the database as this may be regarded as a breach of contract. For example, LexisNexis Butterworth in its terms and conditions states, 
'LexisNexis Butterworths reserves the right to withhold further supplies in the event of any breach of these terms and conditions for any other reason which LexisNexis Butterworths considers warrants such actions' (LexisNexis Butterworth-terms \& conditions, 2007). It can be argued that if LexisNexis Butterworths withholds further supplies, it might inhibit authorized scholars who wanted to copy such content for scholarship.

Also, the incorrect application of the fair use or fair dealing exemption in the digital environment may permit scholars to believe that in a breach of the terms and conditions in the licensing agreement, copyright law is paramount. This is not true. According to Cohen (1998), in a breach of the terms and conditions in the licensing agreement, "contract law rather than copyright law is paramount'.

In the same vain, the incorrect application of the fair use or fair dealing exemption in the digital environment may allow scholars to believe that licences incorporate a fair dealing exemption as the licences do nothing to prevent authorized users from downloading and printing copies of texts for research purposes. It can be argued that this is untrue as licences restrict unauthorized users and forbid authorized users from using the information fairly if the users are subsidiary corporations, institutions, associations, or organizations affiliated with or related to the subscriber. BiblioLine licence agreement says, 'subscriber rights do not extend to unauthorized users including parent or subsidiary corporation, institutions, association, or organizations affiliated with or related to the subscriber' (BiblioLine Annual License and Subscription Agreement, 2007). Hence, where scholars in this type of licence agreement are found to belong to subsidiary corporations, institutions, associations, or organizations affiliated with or related to the subscriber, they are prohibited from downloading and printing copies of texts notwithstanding that it is for scholarship. Where this occurs, it would inhibit scholarship as these scholars would not be able to copy

digital content for scholarship. rights holders may withhold, terminate or possibly suspend access to digital content.

Furthermore, for the seminars or workshop to receive serious attention from scholars they should be facilitated by experts who are versed with aspects of copying for scholarship in the print and digital environment. Also, the seminars or workshops should be under the auspices of the research department in the institution. This is because it is believed that research departments are meant to promote scholarship in institutions as 'they are founded on the idea of scientific inquiry and evaluation' (Argow, 1940).

It can be said that, since it may not be possible for all scholars to attend any organized seminar or workshop on this issue, brochures should be prepared by those responsible for the seminars or workshops and placed at the entrance of the library informing users on why the print media fair dealing exemption cannot be applied in the digital content. Also, notices as to why the print media fair use or fair dealing exemption cannot be applied in the digital content should be placed in front of computers. The notices must emphasize that in the digital content, only the terms and conditions of licensing agreements should be used to copy digital content and if any scholar needs to know why, the scholar should contact the reference librarian. Also, in order to be sure that scholars are aware that the print media fair use or fair dealing exemption is not applicable in the digital content, such reasons should be placed on websites. The reasons should be scanned by the institutions website manager and a link to the scanned reasons for the scholars should be provided from the institutions online access catalogue (OPAC) and all the reasons 'should be made available on all Web pages that link to electronic resources' (Masango, 2007).

\section{Possible solutions?}

It can be said that since it may be possible for scholars and librarians to incorrectly apply the fair use or fair dealing exemption in the digital environment, it may be the responsibility of institutions to educate librarians and scholars of information on how the exemption should apply in the digital environment. This is because an incorrect application of the exemption may be disastrous to both scholars and institutions. This is because rights holders may withhold, terminate or suspend their licensing agreements because of a breach of the agreement. This is likely to occur because in a breach of the terms and conditions in the licensing agreement 'contract law rather than copyright law is paramount' (Cohen, 1998).

In educating librarians and scholars on how the exemption should apply in the digital realm, institutions should set up seminars or workshop on issues related to copying of information for scholarship in the print and digital content. It can be argued that if institutions organize seminars or workshop on this type of issues it may curb possible withholding, termination or suspension of licensing agreements by rights holders because of a breach of an agreement. It is likely that if scholars are not educated on this issue, they are likely to copy digital content just as they do with the print information on the pretext that they have not been told that they cannot do so. Also, it may be said that if librarians are not educated on how copying should be done in the digital environment, they may allow scholars to apply the fair dealing exemption as it is in the digital realm. Where these takes place and it is proven that scholars are applying the exemption in breach of the licensing agreement,

\section{Conclusion}

It can be said that in order to understand how copyright can support scholarship in both the print and digital environment, it is apt to educate and communicate reasons why it is inapt to apply the fair use or fair dealing exemption without changing its content in the digital environment. This is because reproduction as it is known in the print environment is different in the digital environment. In Microsoft v. Business Boost ${ }^{3}$ it was held that loading material into a computer's RAM was a reproduction of a substantial part of the computer program. The material held in the RAM may be reproduced and distributed with ease. In the digital environment computers automatically carry out all kinds of copying. Any Internet user's personal computer makes copies of Web pages that it displays (Litman, 2001), because it involves a substantial reproduction of the material (McDonald, 1999; Litman, 2001). Also, any use of the computer to view, read, reread, hear or otherwise experience a work in digital form requires reproducing that work in a computer's memory (Litman, 1996).

In order to therefore better apply the fair use or fair dealing exemption in the digital content to support scholarship, scholars as well as librarians must be aware that the content of the exemption must be changed. This is because history has shown that this occurred when new reprographic technologies emerged. Following that the digital environment is a new reprographic technology, not until scholars and librarians are educated as to what some of changes in the content of exemption should address, they may continue to apply the exemption as it is in the digital environment. One can argue that such application may be detriment to scholarship when the application breaches licensing agreements. 


\section{References}

Amen, K., Keogh, T., \& Wolff, N. (2002). Digital copyright: A tale of Domestic discord, presented in three Acts. Computer in Libraries, 22(5), 22-27.

Argow, W. W. (1940). The function of a research department in an institution for delinquents. Journal of Criminal Law and Criminology (1931-1951), 31. Septemer-October (3)), 280-290 [aw and Cim 31-03-2008] htp:/ 31(September-October (3)), 280-290 [accessed on 31-03-2008]. http:// 150.pdf?backcontext=page\&dowhat=Acrobat\&config=jstor\&userID= 150.pdf?backcontext=page\&dowhat=Acrobat \&config=jstor\&

Band, J. (2008). Publish and perish? Protecting your copyrights from your publisher. http://www.policybandwidth.com/doc/20080523-PublishANDPerishFinal.pd [accessed on 04-06-2008].

BiblioLine Annual License Subscription Agreement. (2007). http://www.nisc.com subscribe/bibsub.htm\#License [accessed on 05-06-2008].

The British Academy and The Publishers Association. (2008). Copyright and academic research: guidelines for researchers and publishers in the Humanities and social sciences, http://www.britac.ac.uk/reports/copyright-

Cohen, J. E. (1998). Copyright and the jurisprudence of self-help. Berkeley Technology Law Journal, 13, 1089-1143.

Copeling, A. J. C. (1978). Copyright and the Act of 1978. Durban: Butterworths Copyright Act (1976) as amended. (n.d.). Subject matter of copyright: In general http://www.law.cornell.edu/copyright/copyright.act.chapt1a.html\#17usc102 [accessed on 02-06-2008]

Davis, T. L. (1999). Legal issues: The negotiator's perspective for getting to heart of the licence. In Virtually yours: Models for managing electronic resources and services. In P. Johnson \& B. MacEwan (Eds.), Proceedings of the Joint Reference and User Services Association and Association for Library Collections and Technica Services Institute October 23-25, 1997 Chicago, American Library Association, (pp. 118-126).

EBSCO publishing product license agreement. (2005). http://www.cbu edu/library/policies/ebsco.htm [accessed on 24-06-2008].

Digital Millennium Copyright Act. (1998). The Digital Millennium Copyright Act of 1998: Copyright Office Summary. Pub. L. No. 105-304, 112 Stat. 2860 (Oct. 28, 1998) http://www.loc.gov/copyright/legislation/dmca.pdf [accessed on 24-06-2008]

Fowler, D. C. (2005). Licensing: An historical perspective. Journal of Library Administration, 42(3/4), 177-197.

Harper, G. (2001). Will we need fair use in the twenty-first century? http://www utsystem.edu/OGC/IntellectualProperty/fair use.htm [accessed on 24-062008.

Jacobson, G., \& Hillkirk, J. (1986). Xerox American samurai: The behind-the-scenes story of how a corporate giant beat the Japanese at their own game. New York: Macmillan.

Lahore, J., \& Rothnie, W. A. (2004). Digital Agenda-The Copyright Amendment (Digital Agenda) Act 2000. Sydney, Australia: Butterworths., 1-Commentary

Leaffer, M. (1989). Understanding copyright law. New York: Matthew Bender.

LexisNexisButterworth—termsandconditions.(2007).http://www. lexisnexis.co.za/?page=104 [accessed on 24-06-2008].

Litman, J. (1996). Revising copyright law for the information age. http://wwwpersonal.umich.edu/\$\$jdlitman/papers/revising.htm [ accessed on 24-062008].

Litman, J. (2001). Digital copyright. New York: Prometheus.

Loundy, D. (1995). Revising the copyright law for electronic publishing. John Marshall Journal of Computer and Information Law, 14 http://www.loundy.com/RevisingHyperT.html [accessed on 24-06-2008].
Masango, C. A. (2007). Perceptions about copyright of digital content and its effects on scholarship: A South African perspective. Libri, 57(2), 84-91.

Matheson, S. (2002). Access versus ownership: A changing model of intellectual property. In M. Chiorazzi \& G. Russell (Eds.), Law library collection development in the digital age (pp. 153-176). New York: Haworth Information Press, 21(2/3 and 4)

McCracken, R. (2004). Agreements, user licences and codes of practice. In Chris Armstrong, W. Laurence, \& Bebbington (Eds.), Staying legal: A guide to issues and practice affecting the library information and publishing sectors (2nd ed., pp. and practice affecting the library informat

McDonald, I. (1999). Copyright in the new communication: Balancing protection and access http://www.copyright.com.au/reports\%20\&\%20papers/new\% 20communications\% 20 nvironment pdf [accessed on 24-06-2008].

Neacsu, E. D. (2002). Legal scholarship and digital publishing: Has anything changed in the way we do legal research? In Michael Chiorazzi \& Gordon Russell (Eds.), Law library collection development in the digital age (pp. 105-122). New York: Haworth Information Press, 21(2/3 and 4)

Nielsen, J. (2001). Avoid PDF for on-screen reading http://www.useit.com/ alertbox/20010610.html [accessed on 24-06-2008

Patry, W. F. (1995). The fair use privilege in copyright law (2nd ed.). Washington, D.C.:

Peters, T. A. (2003). Was that the Rubicon, Lethe, or Styx we just crossed? Access conditions for e-content. Library Collections, Acquisitions, \& Technical Services, 27, 215-223.

Prytherch, R. (2000). Harrod's librarians' glossary and reference book (9th ed.). Aldershot: Gower.

Rimmer, M. (2004). Canadian rhapsody: Copyright law and research libraries. Australian Academic \& Research Libraries, 35(3), 193-213 http://alia.org.au/publishing/aarl/35.3/full.text/rimmer.html[accessedon 24-06-2008]

ScienceDirect Subscriber Licence. (1999). http://www.griffith.edu.au/ins/collections/ ejournal/elsevier.pdf [accessed on 22-09-2008].

South Africa Statutes. (2000). (10th ed.). Copyright Act 98 of 1978 Juta Law: Lansdowne, Cape Town., pp. 220-234

Sprigman, C. (2002). The mouse that ate the public domain: Disney, the Copyright Term Extension Act, And Eldred v. Ashcroft. FindLaw's legal commentary. Tuesday, Mar 05, 2002 http://writ.news.findlaw. com/scripts/printer friendly.pl?page=/commentary/20020305 sprigman $\mathrm{html}$ [accessed on 24-06-2008].

Trosow, S. E. (2003). The illusive search for justification theories: Copyright, commodification and capital. Canadian Journal of Law and Jurisprudence, 16(2), 217-241.

United States Copyright Act of, 1976. Fair use http://en.wikipedia.org/ wiki/United States Copyright Act of 1976 [accessed on 24-06-2008] 